\title{
Penggalian Motif Ukir Lokal Guna Meningkatkan Kualitas Rumah Ukir Desa Pokaan, Kabupaten Situbondo
}

\author{
Akhmad Sofyan, Panakajaya Hidayatullah \\ Fakultas Ilmu Budaya, Universitas Jember \\ Sofyanakhmad544@gmail.com
}

\begin{abstract}
Abstrak
Rumah ukir di Desa Pokaan merupakan rumah produksi seni ukir dan destinasi wisata edukasi yang diinisiasi oleh masyarakat Desa Pokaan. Direalisasi oleh mahasiswa KKN dan telah dilaunching pada bulan Agustus 2018. Selain menyelenggarakan wisata edukasi untuk masyarakat, rumah ukir juga aktif memproduksi karya seni ukir yang dijual ke Bali baik dalam jumlah yang besar maupun kecil. Seluruh karyawan yang bekerja di rumah ukir merupakan masyarakat usia produktif di Desa Pokaan. Eksistensi rumah ukir diharapkan dapat menumbuh kembangkan minat masyarakat Desa Pokaan untuk bergerak berwirausaha. Mengingat di Desa Pokaan setidaknya ada dua pengrajin ukir dan beberapa masyarakatnya rata-rata terampil mengukir. Mengembangkan wisata edukasi merupakan salah satu upaya untuk membangun kesejahteraan Desa, serta mendukung program pemerintah Kabupaten Situbondo pada tahun kunjungan wisata 2019. Melihat potensi Desa Pokaan yang kaya dengan seni ukir, pada saat launching pemerintah Desa dan Kecamatan berkomitmen bahwa dalam jangka panjang akan mencanangkan (branding) Desa Pokaan sebagai Desa Wisata 'Sentra Ukir'. Ada beberapa kendala yang terjadi di rumah ukir Desa Pokaan, pertama adalah rumah ukir belum memiliki ciri khas (karakteristik) motif dan pola ukirnya sehingga belum cukup mampu untuk membranding potensi lokal Desanya. Kedua teknologi dan metode penggarapan serta mekanisme manajemennya masih menggunakan cara - cara tradisional. Kegiatan pengabdian ini berfokus untuk mengatasi kedua kendala yang dihadapi oleh rumah ukir Desa Pokaan. Melalui penggalian potensi lokal untuk diaktualisasikan ke dalam bentuk motif dan pola ukir sehingga dapat menjadi ciri khas ukiran lokal, serta melakukan pendampingan dan pengembangan skill dalam hal penerapan teknologi, metode dan manajeman produksi.
\end{abstract}

Kata Kunci: pengembangan kualitas, motif lokal, wisata edukasi, rumah ukir, pokaan

\begin{abstract}
The carving house in Pokaan Village is a production house for carving and educational tourist destinations initiated by the Pokaan Village community. Realized by KKN students and launched in August 2018. In addition to organizing educational tours for the community, carvings are also active in producing carved art sold to Bali in large and small quantities. All employees who work in carvings are productive age people in Pokaan Village. The existence of carving houses is expected to grow the interest of the Pokaan Village community to move into entrepreneurship. Considering that in Pokaan Village there are at least two craftsmen carving and some of their people are skilled at carving. Developing educational tourism is one of the efforts to develop the welfare of the Village, as well as supporting the Situbondo District government program during the 2019 tourist visit. Seeing the potential of Pokaan Village which is rich in carving, at the time of launching the Village and District governments committed that in the long run (branding) Pokaan Village as a 'Carving Center' Tourism Village. There are several obstacles that occur in the Pokaan Village carving house, first is the carving house does not yet have the characteristics (characteristics) of the motives and patterns of carving so that it is not yet capable enough to compare the local potential of the village. Both technology and cultivation methods and management mechanisms still use traditional methods. This service activity focuses on overcoming the two obstacles faced by the Pokadn Village carving house. Through excavation of local potential to be actualized in the form of motifs and patterns of
\end{abstract}


carving so that it can become a characteristic of local carvings, as well as assisting and developing skills in terms of the application of technology, methods and production management.

Keywords: quality development, local motifs, educational tours, carving, pokaan

\section{PENDAHULUAN}

Situbondo adalah salah satu kabupaten di Provinsi Jawa Timur. Berada di jalur pantai utara ujung timur pulau Jawa. Umum dikenal dalam pelajaran sejarah Jalan Raya Pos Deandels di masa kolonial, dari Anyer berakhir di Panarukan (Situbondo). ${ }^{1}$ Masyarakatnya beretnis Madura dan Jawa. Kota Santri dan Bumi Salawat Nariyah adalah slogan yang dijadikan identitas daeah. Melihat di Situbondo banyak terdapat pesantren, sehingga masyarakatnya diidentikkan sebagai daerah yang bernafas keislaman. $^{2}$

Namun, sejak 2015, berdasarkan Peraturan Presiden Nomor 131, status Kabupaten Situbondo ditetapkan sebagai daerah tertinggal. Termasuk 122 kabupaten tertinggal se-Indonesia dan 4 kabupaten tertinggal di Provinsi Jawa Timur. Ditetapkannya Kabupaten Situbondo sebagai daerah tertinggal karena masih lemah tingkat kesehatan, pendidikan, infrastruktur, ketergantungan terhadap pemerintah pusat, serta rawan konflik, bencana dan perbatasan. Khusus Situbondo, yang menjadi masalah utamanya ialah mengenai Indeks Pembangunan Manusia (IPM) yang rendah, di bawah rata-rata IPM nasional.

Rendahnya IPM menandakan bahwa manusia (generasi) Situbondo masih belum mampu mengelola potensi yang dimiliki daerahnya. Pada tahun 2018, pemerintah Kabupaten mencoba untuk mengejar defisit ketertinggalannya melalui pencanangan program tahun kunjungan wisata 2019. Universitas Jember sebagai pusat laboratorium kebudayaan dan pusat pendidikan di kawasan Besuki Raya merespon wacana tersebut dengan berkomitmen untuk melaksanakan program pengabdian masyarakat dan kuliah kerja nyata (mahasiswa) yang tematik guna menjawab kebutuhan masyarakat dan tepat sasaran. Khusus di lingkungan Situbondo, tema KKN yang diangkat adalah pengembangan "Desa Wisata dan Wirausaha".

Desa Pokaan adalah salah satu Desa di Kecamatan Kapongan, Kabupaten Situbondo yang termasuk dalam wilayah proyeksi KKN mahasiswa Universitas Jember tahun 2018. Desa Pokaan memiliki berbagai potensi wisata dan wirausaha yang dapat dikembangkan seperti miuman pokka' jhâi (Pokak Jahe) sebagaimana nama tersebut menjadi ikon nama Desanya, serta potensi seni ukir. Perihal potensi seni ukir, dapat dilihat melalui banyaknya masyarakat di Desa ini yang memiliki skill serta keterampilan khusus dalam bidang seni ukir. Berdasarkan pengamatan penulis selaku pembina KKN di Desa KKN periode Juli-September 2018, di Desa ini setidaknya ada dua industri ukir rumahan yang semua pengrajin ukirnya merupakan masyarakat (berasal dari) Desa Pokaan. Dua industri rumahan tersebut bergerak dalam produksi karya seni ukir yang berbeda. Industri pertama berada di Desa Pokaan Barat, secara khusus memproduksi karya seni ukir berukuran kecil seperti gantungan kunci, asesoris rumahan serta hiasan. Industri ukir yang kedua terletak di Desa Pokaan Timur, secara khusus memproduksi karya seni ukir berukuran menengah sampai besar seperti gitar ukir, plakat, papan

\footnotetext{
${ }^{1}$ Edy Burhan Arifin (dkk). 2008. Quo Vadis Hari Jadi Kabupaten Situbondo. Situbondo: Bappekap Situbondo Bekerjasama dengan Kopyawisda Jatim, hal 148.
}

${ }^{2}$ Hidayatullah, Panakajaya. 2017. Dangdut Madura Situbondoan. Yogyakarta: Diandra Kreatif, hal 17-18. 
surfing ukir, jam ukir, ukiran kaligrafi, serta beberapa bentuk ukiran lainnya yang bisa dilayani sesuai dengan kebutuhan pesanan.

Program kerja jangka panjang KKN mahasiswa UNEJ salah satunya adalah mengembangkan Desa Pokaan menjadi "Desa Wisata Edukasi dan Sentra Ukir". Dalam kegiatan KKN yang telah berlangsung, salah satu industri ukir rumahan yang terletak di Desa Pokaan Timur telah berhasil dikembangkan oleh masyarakat Desa bekerjasama dengan pemerintahan Desa dan mahasiswa KKN menjadi "Rumah Ukir". Rumah ukir di Desa Pokaan merupakan rumah produksi seni ukir dan destinasi wisata edukasi yang diinisiasi oleh masyarakat Desa Pokaan. Direalisasi oleh mahasiswa KKN dan telah dilaunching pada bulan Agustus 2018. Selain menyelenggarakan wisata edukasi untuk masyarakat, rumah ukir juga aktif memproduksi karya seni ukir yang sebagian besar diekspor ke luar negeri seperti Italia, dan Amerika. Sebagian lainnya juga dijual ke Bali baik dalam jumlah yang besar maupun kecil. Seluruh karyawan yang bekerja di rumah ukir merupakan masyarakat usia produktif di Desa Pokaan. Eksistensi rumah ukir diharapkan dapat menumbuh kembangkan minat masyarakat Desa Pokaan untuk bergerak berwirausaha. Mengingat di Desa Pokaan setidaknya ada dua pengrajin ukir dan beberapa masyarakatnya rata-rata terampil mengukir.

Mengembangkan wisata edukasi merupakan salah satu upaya untuk membangun kesejahteraan Desa, serta mendukung program pemerintah Kabupaten Situbondo pada tahun kunjungan wisata 2019. ${ }^{3}$ Melihat potensi Desa Pokaan yang kaya dengan seni ukir, pada saat launching pemerintah Desa dan Kecamatan berkomitmen bahwa dalam jangka panjang akan mencanangkan (branding) Desa Pokaan sebagai Desa Wisata 'Sentra Ukir'. ${ }^{4}$ Secara tegas Kepala Desa Pokaan berkoitmen untuk menyiapkan anggaran serta program-program khusus untuk mencapai misi tersebut. Program KKN UNEJ 2018 di Desa Pokaan dinilai oleh beberapa perangkat Kecamatan Kapongan telah memberikan dampak yang signifikan salah satunya dengan jeli telah melihat potensi Desa yang memungkinkan untuk ditindaklanjuti, serta inovasi untuk mengembangkannya menjadi 'rumah ukir' hingga harapannya terwujud sampai menjadi Desa Sentra Ukir. ${ }^{5}$

Rumah ukir Desa Pokaan sebelumnya adalah industri ukir rumahan milik Bapak Fauzi Indra Puji. Terletak di RT 01/RW 04 Dusun Karang Malang, Desa Pokaan (Timur), Kecamatan Kapongan, Situbondo. Fauzi merupakan masyarakat Desa Pokaan yang sebelumnya sempat menjadi pengrajin ukir (buruh) di sebuah perusahaan ukiran di Bali. Selama bekerja di Bali, Fauzi mendapatkan pelajaran dan pengalaman untuk menggarap seni ukir profesional yang berkualitas ekspor dan dipasarkan di pasar internasional. Semenjak dua tahun terakhir, ia memilih untuk berhenti untuk bekerja di Bali karena alasan keluarga dan ingin mengembangkan seni ukir di Desanya. Dengan bekal pengalamannya di Bali, lalu Fauzi melanjutkan usaha seni ukirnya di Desa Pokaan bersama empat karyawan yang seluruhnya adalah tetangganya di Desa Pokaan.

Selama dua tahun terakhir, Fauzi masih bekerja berdasarkan sistem pesanan. Artinya industri ukiran milik Fauzi hanya berproduksi ketika ada orang/perusahaan yang memesan, jika tidak ada maka tidak ada produksi. Sebagian besar pesanannya berasal dari Bali, ia masih menjalankan mekanisme bisnis sistem juragan. Alur kerjanya sebagai berikut: Fauzi mendapatkan pesanan dari juragan di Bali, lalu ia diberi modal

\footnotetext{
${ }^{3}$ Berdasarkan program pemerintah Kabupaten Situbondo melalui website resmi Kabupaten Situbondo di www.situbondokab.go.id, diakses pada tanggal 2 September 2018

${ }^{4}$ Berdasarkan wawancara bersama Kepala Desa dan Camat Kapongan pada tanggal 23 Agustus 2018.

${ }^{5}$ Berdasarkan wawancara bersama Kepala Desa dan Camat Kapongan pada tanggal 23 Agustus 2018.
} 
untuk membeli bahan baku dan menggarap sesuai pesanan juragan. Setelah diberi modal lalu Fauzi mengajak karyawannya untuk menyiapkan bahan baku dan bekerja hingga pesanan selesai. Karya produksinya lalu dikirimkan ke juragan, dan ia diberi bayaran yang disesuaikan dengan tingkat kesulitan garapannya. Artinya Fauzi dan karyawannya hanya dibayar sebagai pengukir, selebihnya ia tidak memiliki kekuasaan untuk menentukan harga karyanya, laba produksi dan lainnya.

Fauzi mengakui bahwa industri rumahan miliknya terkendala oleh modal produksi, padahal menurutnya sebagian besar kliennya berasal dari mancanegara seperti Italia dan Amerika, namun karena mekanisme bisnisnya berjalan demikian, maka hasil yang ia dapatkan tidak maksimal. ${ }^{6}$ Selain itu ia juga terkendala oleh peralatan produksi. Saat ini industri rumahan yang ia jalankan sebagian besar dilakukan dengan teknologi manual, ia hanya memiliki satu mesin pemotong, selebihnya dilakukan dengan keterampilan tangan. ${ }^{7}$ Kurangnya peralatan produksi mengakibatkan produksinya berjalan lambat. Fauzi seringkali mendapat tawaran produksi dalam jumlah yang besar, namun ia selalu menolak karena alasan pengerjaannya yang membutuhkan waktu lama. Berikut contoh beberapa karya produksi Fauzi yang diminati pelanggannya,

Fauzi tidak hanya menjalankan bisnis produksi ukirnya saja, ia juga memiliki impian untuk membuat galeri di Desanya, mengajak anak-anak muda setempat untuk bekerja bersama dan berwirausaha mandiri. Cita-cita terbesarnya adalah menjadikan Desanya sebagai Desa Wisata Sentra Ukir. Kedatangan mahasiswa KKN UNEJ 2018 di Desa Pokaan membuatnya bersemangat untuk mewujudkan impiannya bersama pemerintah, dan masyarakat. Saat ini industri ukir rumahan miliknya telah dikembangkan menjadi "Rumah Ukir", yang di dalamnya berisi galeri karya-karya ukirannya, serta menyelenggarakan program wisata edukasi rumah ukir. Menurutnya wisata edukasi adalah strategi yang bagus untuk menarik minat para remaja dan pelajar di Situbondo kepada seni ukir dan wawasan berwirausaha secara mandiri. ${ }^{8}$ Bisnis wisata edukasi selain memberikan manfaat kepada masyarakat juga merupakan peluang usaha yang meyakinkan dalam menyembut tahun kunjungan wisata Kabupaten Situbondo 2019. Ada beberapa kendala yang terjadi di rumah ukir Desa Pokaan, pertama adalah rumah ukir belum memiliki ciri khas (karakteristik) motif dan pola ukirnya sehingga belum cukup mampu untuk membranding potensi lokal Desanya. Kedua teknologi dan metode penggarapan serta mekanisme manajemennya masih menggunakan cara - cara tradisional.

\section{METODE PELAKSANAAN}

Dalam pelaksanaan kegiatan pengabdian unggulan terhadap Rumah Ukir di Desa Pokaan, Kecamatan Kapongan, Situbondo, akan diterapkan beberapa metode pelaksanaan dan pendampingan. Adapun tahap yang akan dilakukan yaitu persiapan, pelaksanaan pendampingan, dan evaluasi.

\section{A. Tahap Persiapan}

Tahap persiapan merupakan tahap awal yang dilakukan sebelum pelaksanaan pendampingan, meliputi beberapa hal yaitu: observasi awal, memetakan permasalahan, penyusunan rancangan kegiatan pendampingan.

\footnotetext{
${ }^{6}$ Wawancara Fauzi selaku pemilik Rumah Ukir pada 23 Agustus 2018

7 Wawancara Fauzi selaku pemilik Rumah Ukir pada 23 Agustus 2018

${ }^{8}$ Wawancara Fauzi selaku pemilik Rumah Ukir pada 23 Agustus 2018
} 


\section{B. Observasiawal}

Observasi awal dilakukan untuk memahami kompleksitas dan dinamika yang terjadi di dalam Rumah Ukir secara mendalam. Kegiatan ini difokuskan untuk memahami kegiatan rutin yang sudah berlangsung selama ini, melihat keberhasilan, kesulitan serta kekurangannya. Observasi dilakukan meggunakan dua pendekatan yakni pengamatan secara partisipatoris dan diskusi. Pendekatan tersebut dipilih guna mendapatkan informasi dan data awal yang komprehensif, sehingga akan mempermudah dalam melakukan proses pendampingan. Pada saat observasi awal, calon mitra (Rumah Ukir) akan membuat persetujuan kerja sama (MoU) dengan pelaksana kegiatan.

\section{Memetakan permasalahan}

Data yang didapat dari hasil pengamatan melalui observasi awal, kemudian diklasifiasi dan dianalisis. Beberapa masalah yang ditemukan di dalam kedua komunitas tersebut kemudian dipetakan dan dibuat rumusan sehingga akan mempermudah dalam membuat perencanaan kegiatan pendampingan, serta penyusunan solusi pemecahannya.

\section{Menyusun rancangan kegiatan pendampingan}

Guna menghasilkan kegiatan yang efektif dan efisien, maka dibutuhkan rancangan kegiatan yang terstruktur dan sistematis. Rancangan kegiatan disusun berdasarkan hasil dari observasi awal dan pemetaan permasalahan. Penyusunan rancangan kegiatan pendampingan berisikan tentang rincian jadwal kegiatan yang berlangsung selama kurang lebih enam bulan per tahunnya, jenis kegiatan yang akan diselenggarakan mengacu pada permasalahan yang ada, serta metode pendampingan yang seseuai untuk diterapkan dalam pelaksanaan pendampingan.

\section{E. Tahap Pendampingan}

Proses pendampingan dilaksanakan dengan mengikuti skema rancangan kegiatan pendampingan. Pendampingan akan dilakukan setiap minggu secara rutin selama masa pengabdian (enam bulan), dan sewaktu-waktu pasca masa pengabdian. Kegiatan yang akan dilakukan dalam tahap pendampingan ialah berupa beberapa penggalian motif lokal Desa Pokaan, pelatihan tentang wisata edukasi rumah ukir, penyusunan roadmap pengembangan wisata edukasi rumah ukir, dan menjalin kerjasama konstruktif dengan pemerintah daerah. Berikut penjelasan perkegiatannya:

\section{F. Penggalian Motif Lokal Desa Pokaan}

Secara teknis penggalian motif lokal dilakukan secara bersama-sama oleh tim pengabdian, budayawan Situbondo, seniman, pemerintah Desa dan tokoh masyarakat Desa Pokaan. Penggalian motif didasarkan pada idiom-idiom lokal yang ada di Desa Pokaan dan Kabupaten Situbondo secara umum. Motif yang disepakati dari hasil diskusi bersama kemudian diaplikasikan ke dalam karya ukir melalui inovasi-inovasi mutakhir dalam estetika seni ukir. Hasil dari karya tersebut nantinya akan disosialisasikan kepada masyarakat Desa Pokaan dan Kabupaten Situbondo secara umum dengan melibatkan pemerintah Desa, Kecamatan dan Kabupaten. Sosialisasi juga melibatkan beberapa pelajar di Desa Pokaan, berbentuk workshop pengenalan serta praktek membuat seni ukir sederhana dengan motif khas Rumah Ukir Desa Pokaan. 


\section{HASIL DAN PEMBAHASAN}

\section{A. Penggalian Motif Lokal Desa Pokaan}

1. Observasi Rumah Tabing Tongko'

Kegiatan penggalian motif lokal Desa Pokaan, dimulai dari kegiatan observasi. Observasi dilakukan guna menggali dan mengenali apa saja ragam motif ukir yang ada di Situbondo. Observasi di mulai dari pencarian motif yang sudah banyak dikenali di Situbondo. Adapun lokasi observasi dilakukan dan dimulai dari daerah pesisir utara Situbondo. Pesisir utara Situbondo dikenal dengan daerah Pecinan, karena dalam sejarahnya di daerah tersebut merupakan wilayah migrasi pertama orang Cina ke Situbondo. Di daerah tersebut banyak ditemukan motif dan ragam hias yang bercorak Cina. Berikut beberapa contoh motif hias yang terdapat di rumah adat tradisional masyarakat Madura di Situbondo yang dikenal dengan 'Rumah Tabing Tongko'.

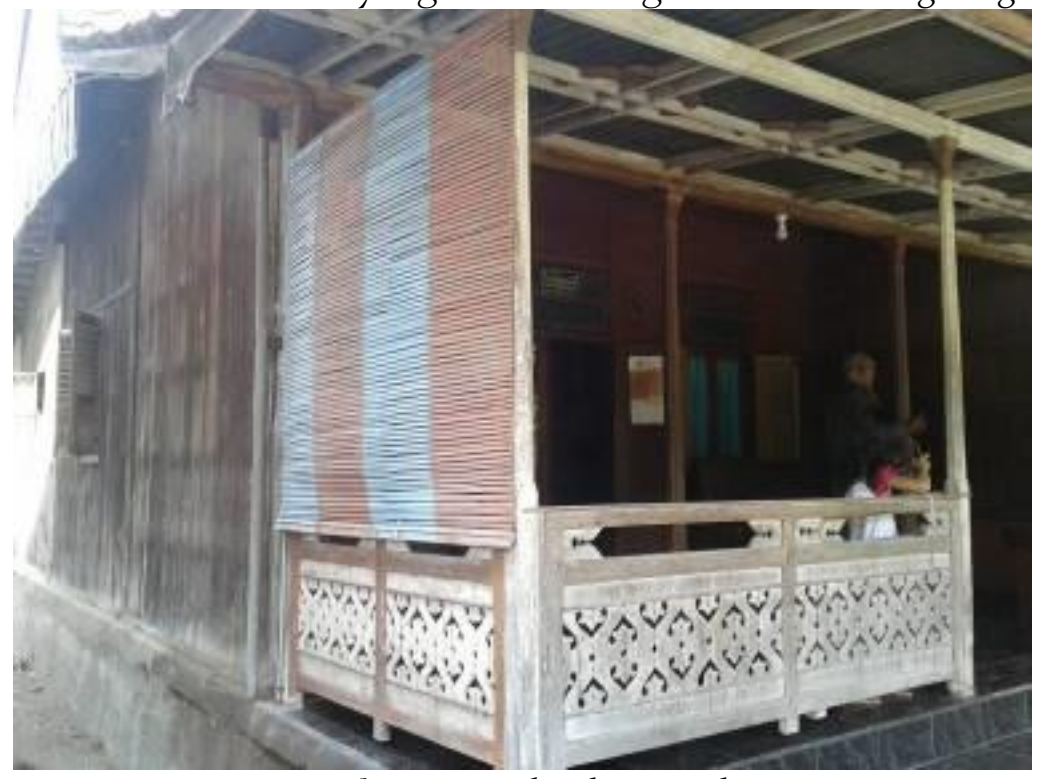

Gambar. 1 Rumah Tabing Tongko'

Sumber: Dokumentasi Pribadi

Gambar di atas merupakan foto rumah tabing tongko' masyarakat Madura di pesisir utara Situbondo. Rumah tabing tongko' memiliki ciri dan karakter motif ukiran pecinan. Motif ukiran itu salah satunya terlihat pada sisi depan rumah yang menjadi batas/pagar ruang teras dengan tanèyan (halaman rumah). Motif yang terdapat pada pagar tersebut masuk pada kelompok jenis ragam hias geometris ${ }^{9}$, dengan motif dasar isen dari Madura sebagai ragam hias pinggiran bernama bhang gonggong. Berikut gambar tampak depan dari rumah tabing tongko',

\footnotetext{
${ }^{9}$ Lihat, M. Soegeng Toekio. 2000. Mengenal Ragam Hias Indonesia. Bandung: Penerbit Angkasa.
} 


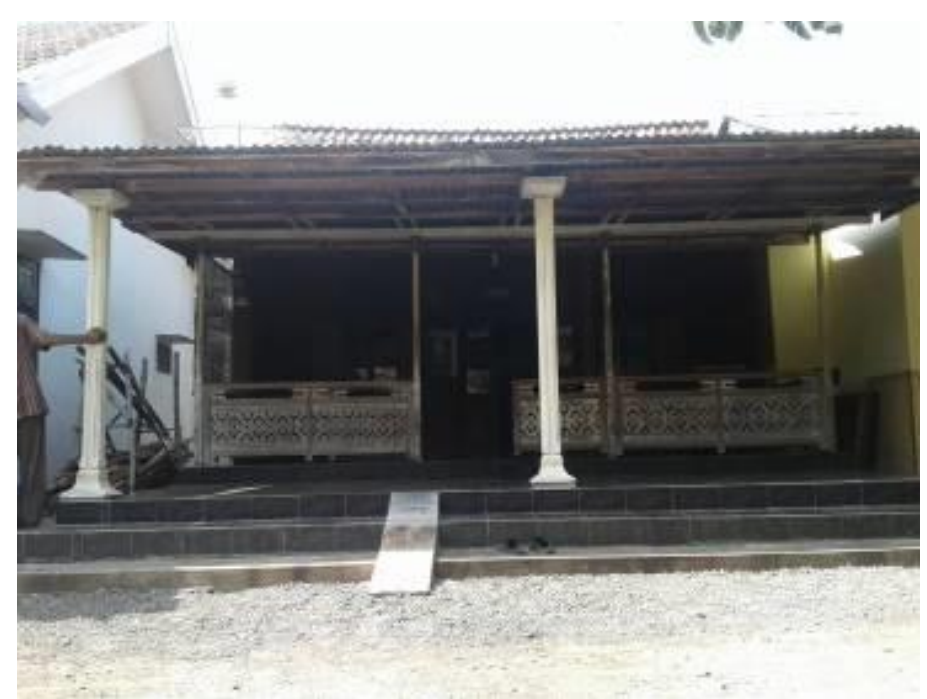

Gambar 2. Rumah Tabing Tongko' tampak depan

Sumber: Dokumentasi Pribadi

Selain ragam hias geometris, di rumah tabing tongko' juga terdapat ragam hias yang lain. Seperti yang terdapat pada hiasan di atas pintu rumah. Ragam hias yang terdapat di atas pintu rumah tabing tongko' merupakan ragam hias tumbuh-tumbuhan (dedaunan) yang menggunakan pengembangan motif soloran (sulur). Berikut gambar ragam hias yang dimaksud,

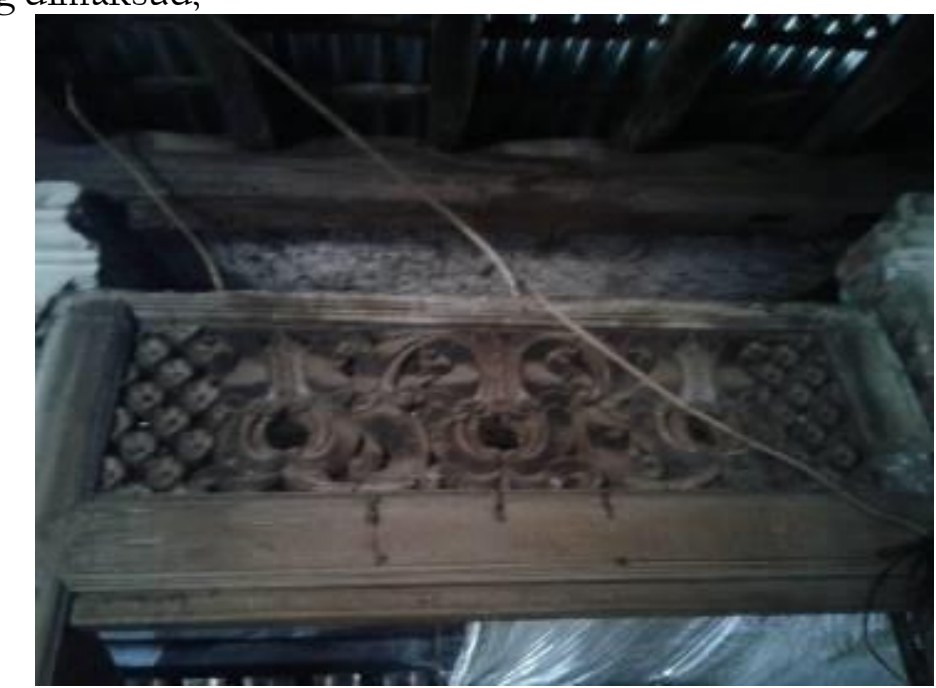

Gambar 3. Ragam hias tumbuh-tumbuhan dengan motif soloran Sumber: Dokumentasi Pribadi

Pada gambar di atas bisa dilihat ragam hiasnya ialah berupa tumbuh-tumbuhan, kemudian dikembangkan dengan motif soloran hingga membentuk beberapa isian. Di sisi pinggir kanan dan kirinya diberi motif isian dengan titik dan garis-garis lengkung. Perpaduan antara ragam hias tumbuh-tumbuhan dengan isian di sisi pinggirnya kemudian membentuk satu ukiran yang menarik.

Di sisi atas rumah (atap) terdapat motif ukiran geometris yang mirip dengan motif trontom Madura. Namun motif tersebut tidak dipenuhi dengan penuh isian sebagaimana motif trontom. Motif yang dipakai hanya menampilkan motif dasar yang membentuk sisi pinggiran motifnya saja. Berikut gambar motif yang dimaksud, 


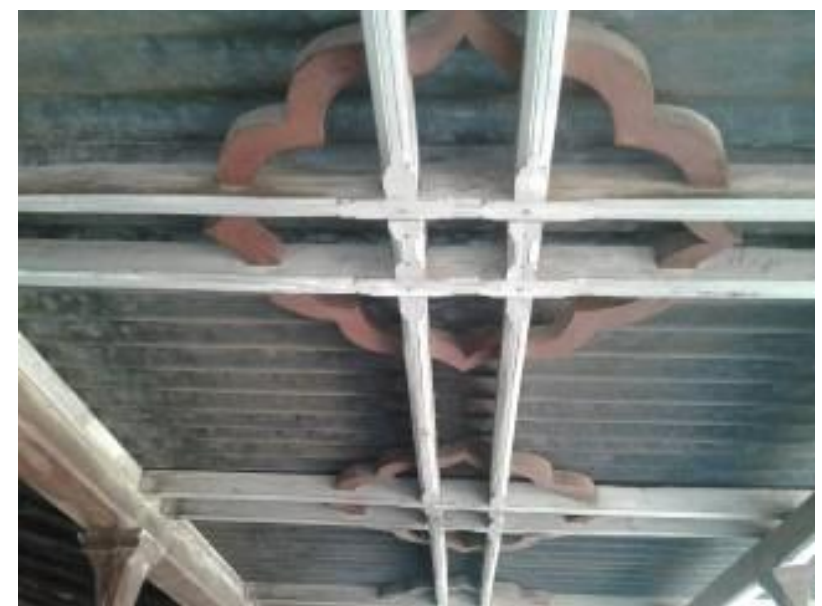

Gambar 4. Ragam hias di atap rumah tabing tongko' Situbondo Sumber: Dokumentasi Pribadi

Motif yang terakhir yakni terdapat pada pintu rumah tabing tongko'. Motif yang terdapat pada pintu rumah adalah motif yang sederhana, karena tidak banyak menggunakan eksplorasi pada motif dasarnya. Motif dasar yang digunakan adalah motif geometris, dengan membentuk persegi (belah ketupat) di tengah-tengahnya serta persegi lima di sisi atas dan bawahnya sebagai covernya, berikut motif yang dimaksud,

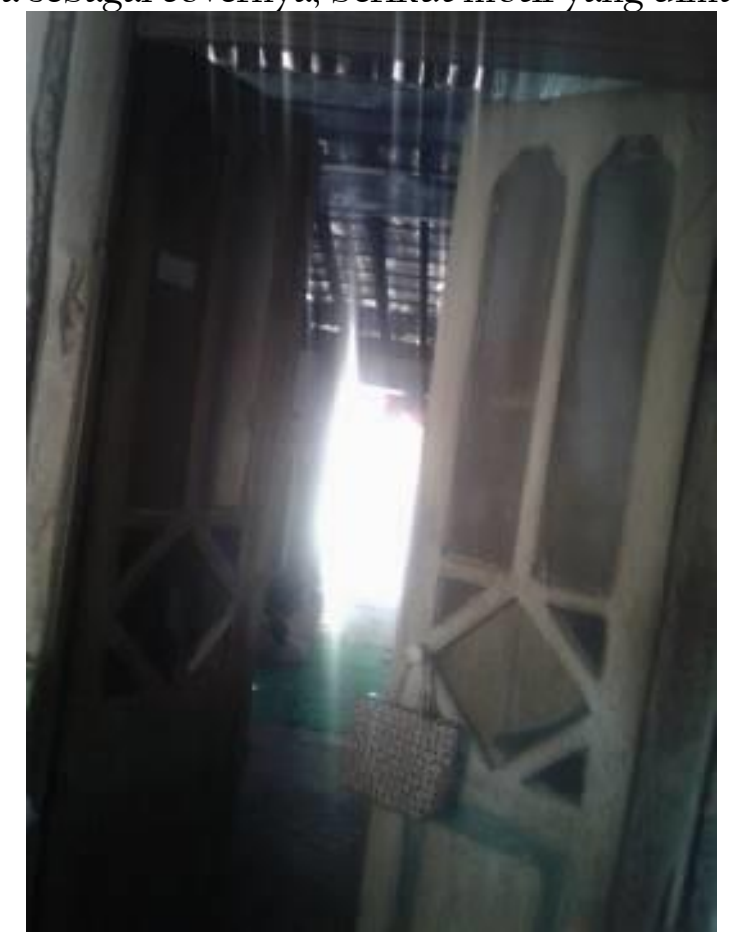

Gambar 5. Ragam hias ukir di pintu tabing tongko' Sumber: Dokumentasi Pribadi

Beberapa motif yang telah dijelaskan merupakan ragam hias dan motif yang umum dipakai oleh masyarakat di daerah pesisir Utara Situbondo. Setelah melakukan penelusuran di daerah Pokaan, ternyata juga masih banyak terdapat rumah tabing tongko'. Beberapa di antaranya memiliki ciri-ciri yang sama pada motif ukirannya, sedangkan sebagian yang lain ada yang menggunakan motif lain dan nampak mirip dengan motif Cina yakni menggunakan motif Swastika. 
2. Observasi Motif Kerajinan Ukiran

Di Situbondo, terdapat beberapa kerajinan ukir yang sudah lama eksis. Beberapa di antaranya menghasilkan bentuk kerajinan ukir untuk cinderamata seperti berbentuk wayang, bunga, jam dinding dan lainnya. Karakteristik ukiran di Situbondo tidak terlalu menunjukkan kerumitan seperti di Bali dan Jepara, motif ukirannya terlihat sederhana dan tidak begitu banyak isiannya. Ukiran hanya terfokus pada bentuk intinya saja. Seperti pada bentuk ukiran wayang punakawan berikut,

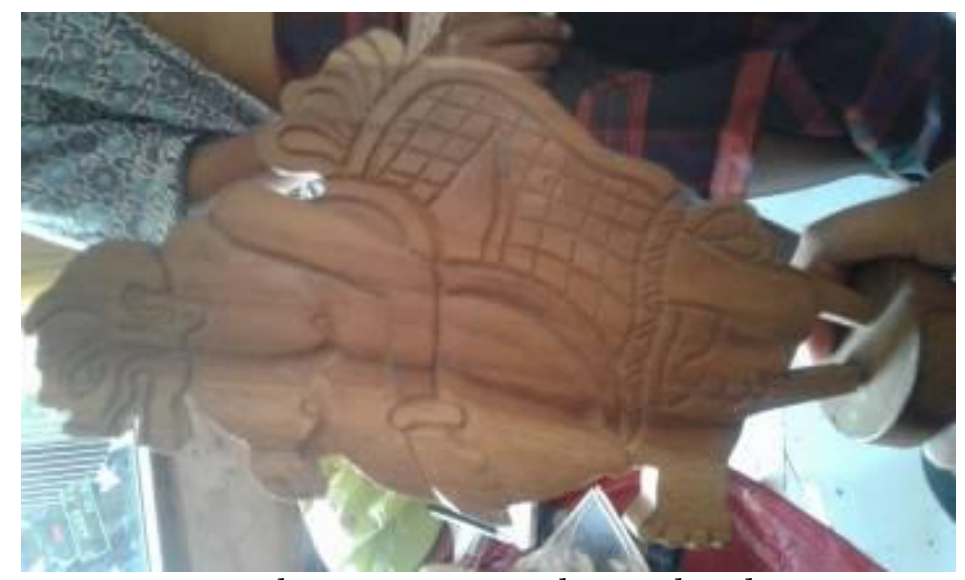

Gambar 6. Kerajinan Ukir Situbondo

Sumber: Dokumentasi Pribadi

Pada gambar 6 bisa dilihat bahwa secara teknik, kerajinan ukir di Situbondo tidak terlalu menunjukkan kerumitan pada pola ukirnya. Isian yang digunakan dalam pola ukirnya juga tidak terlalu ramai.

Di daerah Sumbermalang Situbondo juga terdapat kerajinan ukir yang memproduksi hiasan-hiasan untuk rumah dengan motif ukiran yang khas yakni ragam hias tumbuh-tumbuhan dengan pengembangan soloran (sulur). Salah satunya adalah pada bentuk ghunongan (gunungan) berikut,

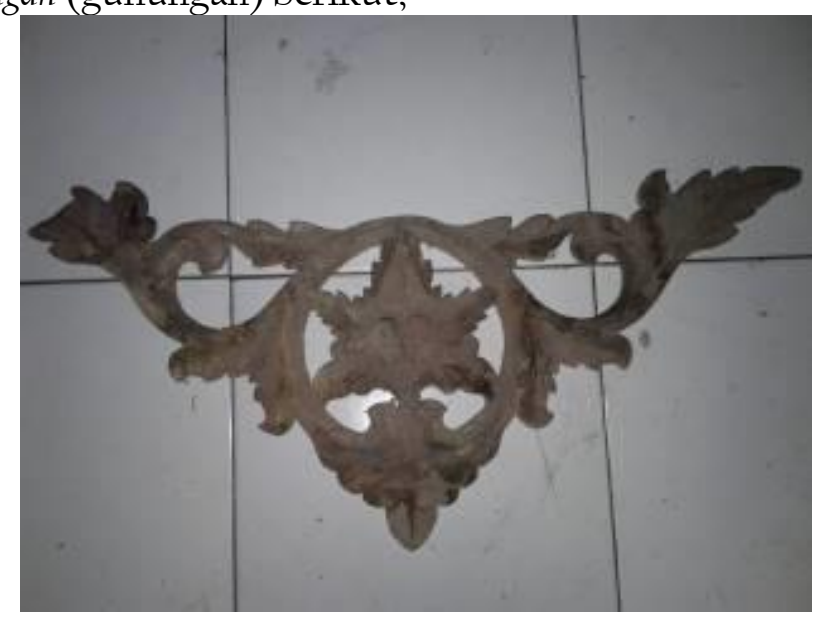

Gambar 7. Ukiran Ghunongan di daerah Sumbermalang Sumber: Dokumentasi Pribadi

Ukiran gunungan tersebut mirip dengan ragam motif tulak angin hanya saja motif yang digunakan di daerah Sumbermalang lebih sederhana dengan menggunakan sedikit isian. 
3. Observasi Motif Batik Situbondo

Selain ragam hias pada motif ukir, ragam hias yang lain juga terdapat pada batik Situbondo. Batik Situbondo memiliki karakteristik khas yang berbeda dari batik Madura maupun Jawa. Motif dasarnya kebanyakan menggunakan ikon hewan laut dan dedaunan (tumbuh-tumbuhan). Karakteristik yang lain dari batik Situbondo adalah minimnya penggunaan unsur-unsur isian, sehingga batiknya terasa sepi dan minimalis. Berbeda dari batik Jawa maupun Madura yang kaya dengan motif isian. Secara pewarnaan, batik Situbondo juga banyak menggunakan warna-warna pastel seperti biru muda, dan hijau muda. Berikut beberapa contoh batk Situbondo yang dimaksud,

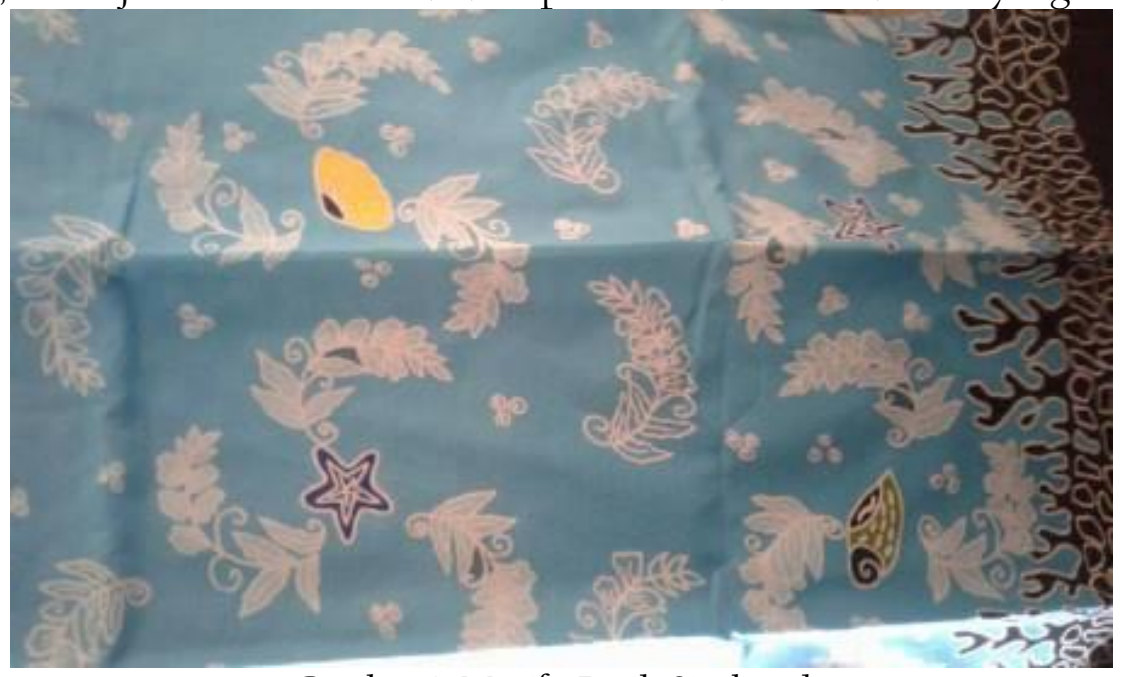

Gambar 8. Motif 1 Batik Situbondo Sumber: Dokumentasi Pribadi

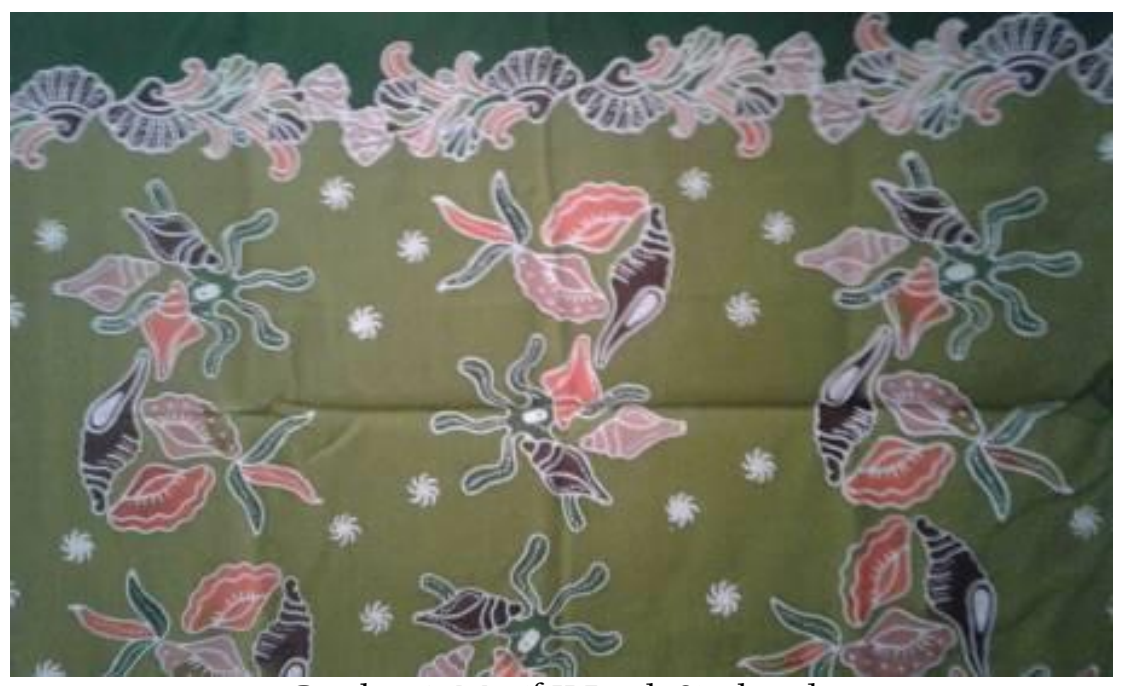

Gambar 9. Motif II Batik Situbondo

Sumber: Dokumentasi Pribadi

Dua contoh batik Situbondo di atas merupakan contoh batik yang menggunakan pengembangan motif kerang dan tumbuhan laut. Penggunaan motif hewan dan tumbuhan laut menggambarkan bahwa Situbondo merupakan daerah pesisir yang memiliki garis pantai terpanjang di pulau Jawa. Selain itu masyarakat Situbondo mayoritas juga bekerja sebagai nelayan. Motif tersebut menggambarkan identitas kultural masyarakat Situbondo. Selain motif tumbuh-tumbuhan dan hewan 
laut, batik Situbondo juga mengeksplorasi hal yang lain, yakni tumbuh-tumbuhan darat dan kombinasi antara unsur laut dan darat seperti contoh berikut,

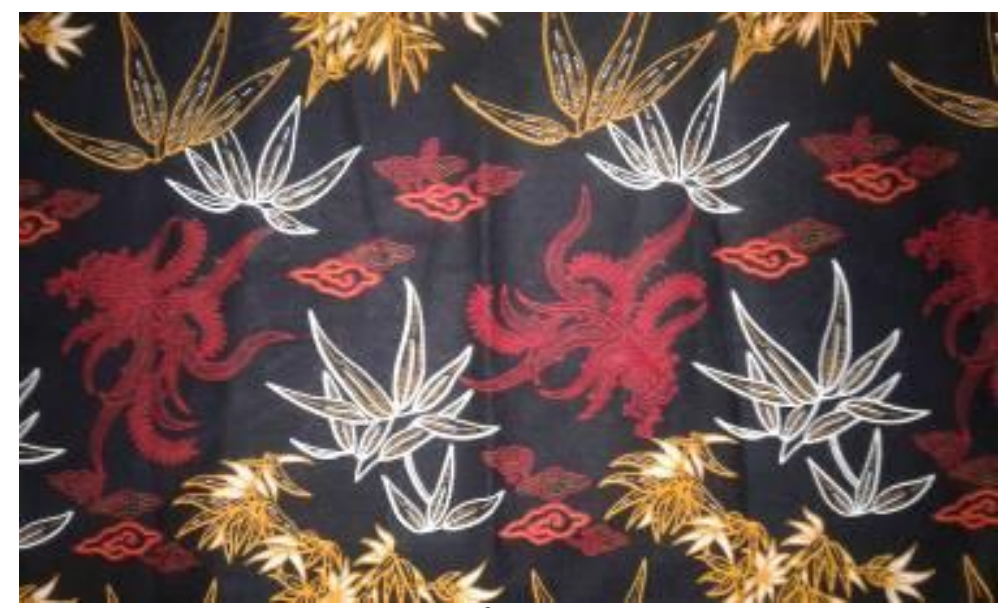

Gambar 10. Motif III Batik Situbondo

Sumber: Dokumentasi Pribadi

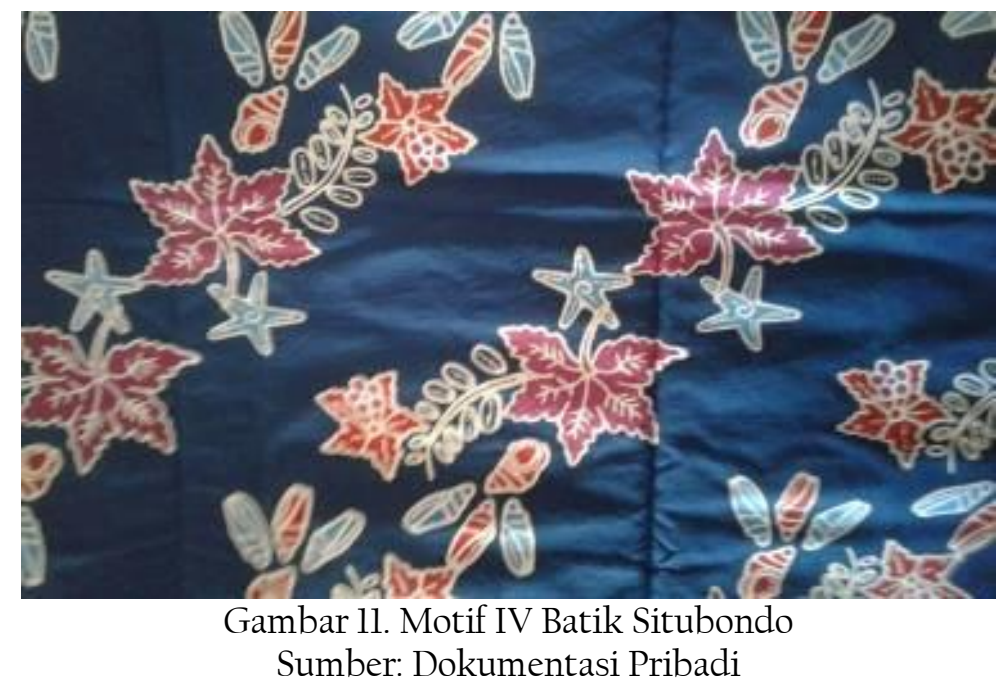

B. Diskusi Perihal Konstruksi Motif Khas Desa Pokaan

Kegiatan selajutnya setelah melakukan observasi lapangan ialah kegiatan diskusi bersama para budayawan, seniman, dan pemilik rumah ukir. Kegiatan ini guna memberi pendalaman atas hasil observasi sebelumnya. Diskusi pertama dilakukan dengan budayawan Situbondo, Imam Kutunuk Fujimaru. Kutunuk merupakan seniman dan budayawan yang secara aktif mengamati perkembangan kebudayaan di Situbondo. Ia memiliki banyak koleksi ragam hias motif Situbondo, dari era pra kolonial, era kolonial sampai pasca kolonial. Koleksinya ia dapatkan dari beberapa kolega dan keluarganya sejak remaja. Dari kegiatan diskusi dengan Kutunuk, dihasilkan beberapa macam rekomendasi, yakni 1) menginventarisir ragam hias yang pernah ada di Situbondo, yang belum sempat diketahui oleh orang umum;2) menentukan model rekayasa motif untuk Desa Pokaan dari hasil kreasi pengembangan motif ukir yang telah dikumpulkan. 


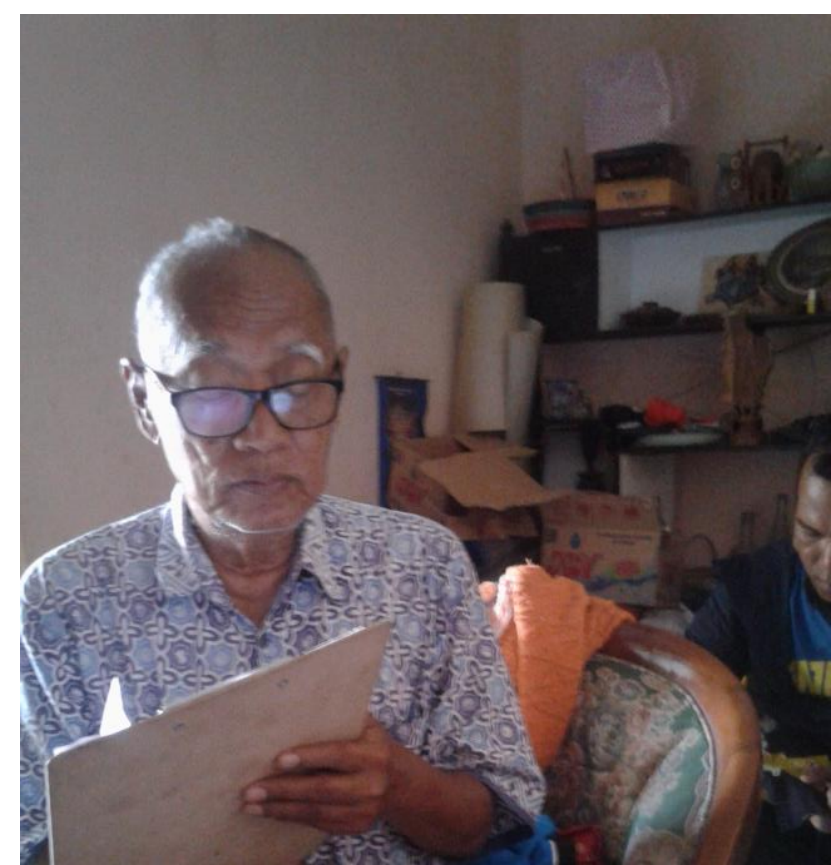

Gambar 12. Imam Kutunk Sedang Mendisain Motif Ukir Situbondo Sumber: Dokumentasi Pribadi

Diskusi yang kedua dilakukan bersama Fauzi selaku seniman sekaligus pemilik rumah Ukir di Desa Pokaan. Diskusi yang dilakukan bersama Fauzi membahas perihal teknis tentang kemungkinan-kemungkinan mewujudkan motif yang telah diinventarisir sebelumnya. Mengeksplorasi beberapa temuan-temuan motif yang ada di Situbondo dan melakukan eksperimen untuk membuat motif-motif tersebut menjadi menarik. Hasil dari diskusi bersama Fauzi menghasilkan beberapa rekomendasi yakni, 1) melakukan eksplorasi dengan menggabungkan beberapa motif yang sudah ada menjadi identitas yang baru dan khas Pokaan; 2) menguji cobakan kepada beberapa pengrajin ukir di Desa Pokaan, apakah motif-motif tersebut sesuai dengan karakteristik Desa Pokaan, dan apakah motif tersebut memungkinkan untuk dijadikan identitas bersama dalam kaitannya dengan teknis memproduksinya dan pemasarannya.

\section{KESIMPULAN DAN SARAN}

Kabupaten Situbondo memiliki banyak ragam hias, di antaranya dapat diamati melalui bentuk rumah adatnya yakni rumah tabing tongko'. Dalam arsitektur rumah tabing tongko' terdapat beberapa macam motif ukiran yakni motif geometris, swastika, isen Madura bhang gonggong, dedaunan, soloran, dan trontom. Melalui kesenian kerajinan ukir juga dapat digambarkan bahwa karakteristik ukir di Situbondo lebih bersifat minimalis, tidak menggunakan banyak teknik ukir yang rumit, tidak banyak menggunakan isen-isen. Di Daerah Sumbermalang Situbondo juga dapat ditemui motif ukiran yang khas yakni ghunongan dengan menggunakan ikon daun-daunan yang dikembangkan dengan motif soloran. Selain ragam hias ukir, ragam hias yang lain juga dapat ditemui pada kesenian batiknya yakni batik Situbondo. Batik Situbondo memiliki karakteristik dengan menggunakan motif hewan dan tumbuh-tumbuhan laut atau kombinasi di antara keduanya, bentuknya simpel dan tidak banyak menggunakan motif isen sehingga batiknya terlihat sepi dan minimalis. Melalui beberapa ragam hias yang telah diinventarisir inilah kemudian dapat dilakukan beragam kombinasi, pengembangan 
secara kreatif serta teknik eksperimentasi guna menemukan dan mendapatkan konstruksi motif yang khas sebagai branding wisata rumah ukir di Desa Pokaan.

Kegiatan ini tentunya membutuhkan keberlanjutan, sehingga program-program yang direncanakan bisa terealisasi dengan baik setiap tahunnya. Butuh dukungan dari masyarakat Desa Pokaan, dan pemerintahan Kabupaten Situbondo supaya tujuan untuk menjadikan Desa Pokaan sebagai Desa Sentra Industri Ukir Tercapai.

\section{DAFTAR PUSTAKA}

Edy Burhan Arifin (dkk). 2008. Quo Vadis Hari Jadi Kabupaten Situbondo. Situbondo: Bappekap Situbondo Bekerjasama dengan Kopyawisda Jatim.

Hidayatullah, Panakajaya. 2017. Dangdut Madura Situbondoan. Yogyakarta: Diandra Kreatif.

M. Soegeng Toekio. 2000. Mengenal Ragam Hias Indonesia. Bandung: Penerbit Angkasa. 